\title{
The effectiveness of using puzzles in developing Palestinian tenth graders' vocabulary achievement and retention
}

\author{
Awad Soliman Keshta ${ }^{1}$, Fikry Kamel Al-Faleet ${ }^{2}$ \\ ${ }^{1}$ The Islamic University of Gaza \\ ${ }^{2}$ Ministry of Education, Gaza, Palestine
}

\section{Email address:}

Dr.awadk@yahoo.com(A. S. Keshta), fikry2005@hotmail.com(F. K. Al-Faleet)

\section{To cite this article:}

Awad Soloman Keshta, Fikry Kamel Al-Faleet. The Effectiveness of Using Puzzles in Developing Palestinian Tenth Graders' Vocabulary Achievement and Retention. Humanities and Social Sciences. Vol. 1, No. 1, 2013, pp. 46-57. doi: 10.11648/j.hss.20130101.16

\begin{abstract}
This study aimed to investigate the effectiveness of using puzzles in developing tenth graders vocabulary achievement. It also examined the long-term effect of the puzzles on the retention of the vocabulary. The researchers purposively chose 80 tenth graders from Abdul Kareem Al-Aklook secondary School for boys in Dair Al Balah for the experiment and randomly chose two classes from the tenth grade classes. The sample of the study was 80 students, (40) students in each one. Educational Puzzles were used in teaching the experimental group, while the traditional method was used with the control one in the second term of the school year (2012-2013). The experiment lasted for six weeks. After two weeks, a delayed test was administrated to the experimental group to measure retention. The results of the study revealed that there were significant differences in mean scores of vocabulary test in favor of the experimental group in the post application. It also showed that there were no significant differences in mean scores between the post-test and delayed test of the experimental group. And this was due to the method of using puzzles in teaching vocabulary. In the light of those findings, the study recommended the necessity of implementing puzzles in teaching English language to make better outcomes in students' achievement and to shed light on techniques that emphasize organizing information for long learning (retention).
\end{abstract}

Keywords: Education, Puzzles, Teaching English, Game

\section{Introduction}

Language plays an essential role in making people communicate with each other. And as for English, it is considered one of the most important languages all over the world. It helps communicating with foreigners at home and abroad. Accordingly, The English language is widely used in science, technology, computer services, politics, commerce and internet. Hence, many countries emphasize the importance of teaching English to their citizens. Richards (2001: 1) believes that "Second and foreign language teaching is one of the world's largest educational enterprises and millions of children

and adults worldwide devote large amounts of time and efforts to the task of mastering a new language". The English language has a special place in the world today. It has become an international language, both in the sense that it is now the native language of people from several continents and in the sense that many others have learnt to speak it as a second language (Graddol, Cheshire\& Swann,1987:3). Ardeo (2003:110) states that during the last few decades there has been an increasing need to use the English language for the expression of knowledge within specific professional fields.

In order to achieve a successful process of learning English, one must acquire its vocabulary, grammar, pronunciation and the

Four skills: listening, reading, speaking, and writing. Accurate and adequate vocabulary influences language comprehension more than grammatical correctness in effective communication. In this concern, Wilkins (1972:111) emphasizes that "Without grammar very little can be conveyed, without vocabulary nothing can be conveyed". This clarifies the importance and the essential role of vocabulary in learning a foreign language.

Vocabulary is a vital part of language that students need to master in order to communicate effectively. Moreover, it is considered the base for the other skills. The ability to grasp 
the meaning of new words is a necessary skill to strengthen reading and listening comprehension. This can positively impact overall academic success and can develop skills for real world applications. This calls for more attention to this important skill. The researchers have observed that students face serious problems regarding this aspect of language.

Students tend throughout learning stages to favor interesting methods which make interacting, exciting and fun learning. This motivated the researcher to conduct this study which aimed to investigate the effectiveness of using puzzles on developing tenth graders vocabulary achievement. It also examined the long-term effect of the puzzles on the retention of the vocabulary.

\section{Statement of the Problem}

The researchers have observed that students face big difficulties in English vocabulary achievement and retention. This difficulty might be a result of ineffective vocabulary teaching methods which affect their vocabulary achievement and retention. Thus, the students' low achievement level in vocabulary requires a serious research for alternative and effective techniques that may increase students' achievement and motivation.

and adults worldwide devote large amounts of time and efforts to the task of mastering a new language". The English language has a special place in the world today. It has become an international language, both in the sense that it is now the native language of people from several continents and in the sense that many others have learnt to speak it as a sec Research Questions

- $\quad$ Are there statistically significant differences at $(\alpha \leq$ 0.05 ) in the total mean score in vocabulary achievement between the pupils who learned through puzzles (experimental group) and those who learned through the traditional method (control group ) in the post test?

- $\quad$ Are there statistically significant differences at $(\alpha \leq$ 0.05 ) in the mean score in the pre and post-test of the experimental group?

- $\quad$ Are there statistically significant differences at $(\alpha \leq$ 0.05 ) in the total mean score between the post-test and delayed test of the experimental group ?

\section{Knowing a Word}

Words are the tools we use to think, to express ideas and feelings, and to learn about the world. Because words are the very foundation of learning, improving students' vocabulary knowledge has become an educational priority. Student word knowledge is strongly linked to academic accomplishment, because a rich vocabulary is essential to successful reading comprehension. Furthermore, the verbal sections of the high-stake standardized tests used in most states to gauge student performance are basically tests of vocabulary and reading comprehension (Johnson \& Johnson, 2004).
Laraba (2007:136) concludes that "foreign language vocabulary learning is determined by the similarities that may exist, at different levels, between the first language and the second or foreign language learnt. Nation (1990: 31) proposes the following list of the different kinds of knowledge that a person must master in order to know a word:

- The meaning(s) of the word

- The written form of the word

- The spoken form of the word

- The grammatical behavioral of the word

- The collocations of the word

- The register of the word

- The associations of the word

- The frequency of the word

From the above mentioned, the researchers conclude that knowing a word includes student ability to recognize the meaning, memorize the word, and use it appropriately in different situation .

\section{Vocabulary Retention in Language Learning}

Vocabulary retention is an essential factor in learning English as a foreign language. Vocabulary retention has been defined as "the ability to recall or remember things after an interval of time. In language teaching, retention of what has been taught (e.g. grammar rules and vocabulary) may depend on the quality of teaching, the interest of the learners, or the meaningfulness of the materials" Richards \& Schmidt (2002 cited in Khabiri \& Pakzad 2012:80). Mohammed (2009:16) defines vocabulary retention as "the ability to keep the acquired vocabulary and retrieve it after a period of time to use it in different language contexts."

Thornbury (2002:23) indicates that learning is remembering, the learner needs not only to learn a lot of words, but to remember them. Bahrick (1984) states that how well people remember something depends on how deeply they process it. Therefore, various procedures have been recommended to facilitate retention.

Therefore, various procedures have been recommended to facilitate vocabulary retention.

To retain the meaning of a word, learners must engage in a deeper analysis of the word's properties rather than simply understand its meaning in context. In the context of word learning, a deeper level of processing means a stronger connection between the word form and its meaning (Craik \& Tulving, 1975).

For long-term recall, the successful learner not only can analyze and rehearse the new word and its meanings, but also can elaborate the word-meaning complex and establish it within a suitable network of meaning. This elaboration probably increases the chances that the word and its meaning will be available for use at a later time (Lawson $\&$ Hogben 1996 :104).

Haycraft (1978 cited in Khabiri \& Pakzad 2012) states 
that the words which are related to each other can be easily retained, because using the meaning of words together with the whole meaning of the sentences in which they are embedded is the deepest level of processing and ensures the best retention.

\section{Teaching Second Language Vocabulary}

English language, like any other language, has different areas that students should study, such as vocabulary, grammar, spelling, listening and reading. In the past, vocabulary teaching and leaning were often given little priority in second language programs, but recently there has been a renewed interest in the nature of vocabulary and its role in learning and teaching (Richard\& Renandya,2002:255) . Decarrico (2001) states that words should not be learnt separately or by memorization without understanding. Moreover, "learning new words is a cumulative process, with words enriched and established as they are met again",

From the researcher's EFL/ESL teaching experience, vocabulary teaching in class was less focused on than teaching English grammatical rules, as a part of the school syllabus. The grammar translation method plays a prominent role in the English classroom. In terms of knowing a word, vocabulary teaching in the classroom was simply restricted to give learners a long list of English words together with Arabic translations. Thus, the learners basically learned two things: the English or L2 word form and the Arabic translation. Extra information about new words (e.g. English definitions, synonyms antonyms, etc.) was optional, depending on whether or not each individual teacher provided the extra information. The learners were normally asked to learn/memorize words on their own. Fox (1987, cited in Tassana-ngam, 2004:17) clarifies that "Students had been learning foreign languages by a grammar translation method which flooded them with new vocabulary items and grammatical structure, but did not allow time to assimilate them much.'It can be said perhaps that learners had little interest or enjoyment when learning and acquiring vocabulary. Allen \& Valette (1977:149) indicate that words are generally taught in context .Thornbury $(2002,22)$ focuses on the teacher role of encouraging an enthusiasm for vocabulary acquisition, and provides learners with strategies for self-directed learning.

\subsection{Techniques of Vocabulary Presentation}

Presenting new vocabulary or reviewing previous vocabulary is a very important part of an English language lesson. Proper presentation and checking can help students in remembering the new vocabulary and quickly understand the meaning. There are different techniques to present vocabulary in the following table from Gairns, R. \& Redman, S. (1986).

\begin{tabular}{lll}
\hline Visual techniques & Verbal techniques & Miscellaneous \\
& & \\
flashcards & illustrative & \\
miming & situation & \\
blackboards & contrasts & \\
drawings & illustrative & contextual guesswork \\
gestures & examples & peer teaching \\
realia & synonyms & dictionaries \\
wallcharts & definitions & \\
scales & opposites & \\
\hline
\end{tabular}

Scrivener (1994:83) points out many vocabulary practice activities as follows:

- $\quad$ matching pictures to words

- matching parts of words to other parts, e.g. beginnings and endings

- matching words to other words, e.g. collocations, synonyms, opposites, sets of related words, etc.

- using prefixes and suffixes to build new words from given words

- classifying items into lists

- using given words to complete a specific task

- $\quad$ filling in crosswords, grids or diagrams

- $\quad$ filling in gaps in sentences

- memory games

\section{Puzzles}

Puzzle is defined as a game that tests your knowledge, skill, intelligence (Oxford Wordpower, 2002). According to (Wikipedia) it is defined as a problem or enigma that tests the ingenuity of the solver

According to Farlex (2009) puzzle is something, such as a game, toy, or problem that requires ingenuity and often persistence in solving or assembling.

The researchers define puzzle as a confusion situation which requires a solution

\subsection{Types of Puzzles}

The researchers is going to handle the types of puzzles as discussed in different books and researches as follows:

\subsubsection{Picture Puzzles}

Spot the difference is a type of puzzle where players must find a set number of differences between two otherwise similar images, whether they are illustrations or photographs that have been altered with photo manipulation. Spot the difference games are also known as photo hunt games, and are commonly found in activity books for children or in newspapers.

\subsubsection{Word Game}

As photo hunt games, and are commonly found in activity books for children or in newspapers.

\subsubsection{Word Game}

According to Jung (2005:4), "games encourage, entertain, teach, and promote fluency and communicative skills". 
Deesri (2002:1) indicates that games are regarded as very useful and important strategy to stimulate language acquisition. They are defined as a form of play concerning competition, rules and fun. Therefore, teachers should use games in teaching to attract students' attention, decrease students' stress and give them the opportunity to communicate effectively. Word games and puzzles are spoken or board games are often designed to test ability with language or to explore its properties. Solving crossword puzzles, which requires familiarity with a larger vocabulary, is a pastime that mature adults have long credited with keeping their minds sharp (Wikipedia). Thus, word game provokes thinking and stimulates language acquisition.

\subsubsection{Anagram}

Anagram is a type of word play, the result of rearranging the letters of a word or phrase to produce a new word or phrase, using all the original letters exactly once; for example orchestra can be rearranged into carthorse. Someone who creates anagrams may be called an "anagrammatist". The original word or phrase is known as the subject of the anagram.

\section{Using Puzzles in Teaching}

ESL/EFL specialists often justified the use of games with reference to the motivation that they can provide for the students. "Games are, by definition, fun, and nearly everyone would agree that if learning can be made enjoyable, then students will learn more" (Celce-Murcia and Macintosh, 1979: 56). "The use of word games to teach vocabulary does not mean or suggest pleasant ways of passing the class time. The entertainment of students is not a teacher's responsibility" (Allen, 1983:10). Rather, teachers are responsible for creating a constructive classroom atmosphere, which encourages vocabulary expansion, and "a well-chosen game can help the students acquire words correctly and feel that certain words are important and necessary because without those words, the objective of the game cannot be achieved" (Allen, 1983:10). The main reasons behind most students' enthusiasm for puzzle-based learning are: Puzzles are educational, but they illustrate useful (and powerful) problem-solving rules in a very entertaining way. Puzzles are engaging and thought-provoking (Michalewicz\& Michalewicz, 2008).

When teachers present vocabulary to the students, they activate students' interest and curiosity. Research studies have clearly established the importance of Puzzles in the learning process. Research studies indicate that puzzles are wonderful tool for helping learners develop skills necessary to read, write and problem solve. They can also grab learner attention and help them develop a better attention. Thus, By effective selecting and implementing of instructional strategies based on puzzles, teachers can better support students on their learning and succeeding throughout the curriculum.

Responsibility" (Allen, 1983:10). Rather, teachers are responsible for creating a constructive classroom atmosphere, which encourages vocabulary expansion, and "a well-chosen game can help the students acquire words correctly and feel that certain words are important and necessary because without those words, the objective of the game cannot be achieved" (Allen, 1983:10). The main reasons behind most students' enthusiasm for puzzle-based learning are: Puzzles are educational, but they illustrate useful (and powerful) problem-solving rules in a very entertaining way. Puzzles are engaging and thought-provoking ( Michalewicz\& Michalewicz, 2008).

When teachers present vocabulary to the students, they activate students' interest and curiosity. Research studies have clearly established the importance of Puzzles in the learning process. Research studies indicate that puzzles are wonderful tool for helping learners develop skills necessary to read, write and problem solve. They can also grab learner attention and help them develop a better attention. Thus, By effective selecting and implementing of instructional strategies based on puzzles, teachers can better support students on their learning and succeeding throughout the curriculum.

\section{Previous Studies}

Chen et al (2012) the paper provides an account of learning arithmetic skills in a more interesting way through the collaborative playing of a puzzle game. 83 students in three classes in Grade 4 were asked to solve arithmetic problems with three different methods: via playing an adapted "cross number puzzle" game on Group Scribbles (GS) collaboratively, via playing the same game on GS individually, and via the traditional method of teaching and learning, i.e. with no games at all. Analysis of the pre and post learning achievement data reveals that the two classes who played the game performed better than the control class, with the collaborative class students achieving better than the individual class students. By playing the game, low-ability students, in particular, made the most significant progress in arithmetic capability and in building up their confidence in doing arithmetic calculations significant progress in arithmetic capability and in building up their confidence in doing arithmetic calculations

Atawi(2011) The purpose of this study is to investigate the effect of using word games on first grade students' achievement in English vocabulary in Al Muthana bin saad school for boys, and Tahfeeth Al Quran school for girls in Tabouk city in Saudi Arabia. To achieve the purpose of the study, a pre/post test was constructed to measure students' level in English vocabulary .The sample of the study consisted of 178 first grade students;(86) male and (92) female students during the first semester of the academic year 2011. The sample of the study was distributed into four groups (two female groups (experimental and control) and two male groups (experimental and control).The experimental groups were taught English vocabulary using games while the control groups were taught using the 
conventional method. The subjects were 44 male students for the experimental group and 42 male students for the control group, while the female students for the experimental and control group were 47 and 45 respectively. Descriptive statistical analyses were used (means and standard deviation) for the pre and post- tests of students' English vocabulary. Comparison statistical methods were used Two Way ANOVA analysis of variance to make a comparison between the control and the experimental groups and gender variable. The findings of the study indicated that there were statistically significant differences in the post- test between the control and the experimental groups in favor of the experimental group, and there was no statistically significant difference in the students' achievement due to gender.

Alemi(2010) This study investigates the role of using word games in expanding the learner's vocabulary. In so doing, an experiment using five word games, named Twenty Questions, Charades, Definition Game's, Passwords, and Crossword Puzzles respectively was conducted. The participants were selected randomly from a male/ female group of third grade junior high school students studying private school.

At a private school First, a standardized test was administered to 100 students out of which 60 almost homogeneous students were selected and randomly divided into two groups: experimental and control. Both groups were taught words using traditional methods, however, the experimental group received word games as a treatment at the end of each session. Finally, a vocabulary test was administered to both groups to determine the differences between them. The score obtained from the groups were compared through independent t-test. The calculated $t$ exceeded the t-critical value, confirming the positive effect of word games on expanding learners' vocabulary.

Bouteliaten (2010) This research work aimed at investigating the effectiveness of using crossword puzzles as a teaching technique to enhance first year English students' knowledge of new foreign vocabulary items. In this respect, the learner-centered method can be applied to our study in which the learner can practice crossword puzzles to improve their knowledge of vocabulary and the teacher is merely a guide. To achieve such an aim, we relied on two means of research: the teachers' questionnaire and the test. First, the teachers' questionnaire was to collect data about the techniques they use when teaching new words in their lessons and their concerns about the affective side of the learner, whether they incorporate crossword puzzles as a teaching strategy to teach new vocabulary items in their classes. Second, for our study, a pre-test and a post-test were organized. In the pre-test, students were supposed to fill-in themed crossword puzzles with the appropriate word (down and cross). The main aim is to teach students new words, and to see the extent to which students are able to decipher the meaning of the clues, as well as the degree of students' familiarity with them. In the post-test, students were asked to write a paragraph about the puzzles' theme. In this respect, the goal intended is to see the extent to which students are able to make a link between the two activities. It is also to measure the degree of influence of using crossword puzzles for the acquisition of new words. The result showed that the learners proved to have learnt nearly all the unfamiliar vocabulary items that they have dealt with in the pre-test (puzzles). They have also manifested a great enthusiasm in this type of material while teaching them. Accordingly, it is recommended that puzzles should be incorporated in teaching materials.

Merrick(2010) This study describes an adaptation of puzzle-based learning to teaching an introductory computer programming course. Students from two offerings of the course--with and without the puzzle-based learning--were surveyed over a two-year period. Empirical results show that the synthesis of puzzle-based learning concepts with existing course content improves students' learning experience by increasing their interest and participation in the course and developing their critical thinking skills.

\section{Methodology}

This study aimed to investigate the effectiveness of using puzzles in developing tenth graders vocabulary achievement. It also examined the long-term effect of the puzzles on the retention of the vocabulary

\subsection{Research Design}

The researchers adopted the quasi experimental approach. Two groups were assigned as the participants of the study; the experimental group, and the control group. The research includes four variables; the first variable is puzzles, the second variable is vocabulary achievement, the third variable is vocabulary retention, the fourth is students' attitudes towards English. The experimental group was taught vocabulary via puzzles, while the control group was taught via the traditional method. The experiment lasted for six weeks. Both groups were taught by the same teacher, the researchers (Al-Faleet).

\subsubsection{Population of the Study}

The population of the study consists of all tenth graders at the governmental schools in the Middle-Area Directorate enrolled in the second semester of the school year (2012-2013).

\subsubsection{Sample of the Study}

The sample of the study consisted of (80) students distributed into two groups; one experimental group consists of (40) students and one control group includes (40) students. The sample of the study was chosen purposively from Abdul Kareem Al-Aklook secondary School for boys in Dair Al Balah. The sample of the study was randomly chosen from the tenth grade classes and equally divided into two groups, experimental and control. 
Table.1. The distribution of the sample according to the groups

\begin{tabular}{cccc}
\hline Group & Experimental & Control & Total \\
\hline No. of sample & 40 & 40 & 80 \\
\hline
\end{tabular}

Both groups were all in grade ten aged nearly 15 . They were chosen from the same school. They were equivalent in their general achievement in accordance with the statistical treatment of their results in the first term of the school year (2012-2013). In this year, all classes were equivalent in their achievement as they were distributed according to their achievement in equivalent classes. A pre-test was used to check the equivalence of achievement between the two groups.

\subsubsection{The Variables of the Study}

The study included the following variables:

1. The independent variable represented in the puzzles

2. The dependent variable represented in the tenth graders' English vocabulary achievement, retention.

\section{Instrumentation}

The researchers used three different instruments to achieve the aims of the study:

1-Vocabulary test (Pre - post \&delayed test)

2-Teacher guide (puzzles).

\subsection{Vocabulary Test}

The achievement test was prepared by the researchers to measure the student's achievement in vocabulary. It was used as a pre test applied student's achievement in vocabulary. It was used as a pre test applied before the experiment, as a post test after the experiment and as a delayed test applied two weeks after the post test.

\subsubsection{The General Aim of the Test}

The test aimed at measuring the effectiveness of using puzzles on developing tenth graders' vocabulary achievement, retention and their attitudes towards English language.

\subsubsection{The Sources of Constructing the Test}

The researchers depended on "English for Palestine 10 "textbook to form the vocabulary test. Furthermore, he depended on his experience as an English teacher. Moreover, the researchers consulted the English supervisors in west Gaza and middle area governmental schools and some English teachers.

Table 2. The Distribution of the Vocabulary Achievement Test

\begin{tabular}{cccc}
\hline Question & Type & $\begin{array}{c}\text { Number } \\
\text { of Items }\end{array}$ & Marks \\
\hline Question1 & $\begin{array}{c}\text { Fill in the spaces with the right } \\
\text { words from the box } \\
\text { Complete the sentences with a } \\
\text { Question2 }\end{array}$ & 6 & 6 \\
& $\begin{array}{c}\text { suitable word from the same } \\
\text { word family }\end{array}$ & 5 & 5 \\
\hline
\end{tabular}

\begin{tabular}{lccc}
\hline Question3 & $\begin{array}{c}\text { Match the words on the left to } \\
\text { the definitions on the right } \\
\text { Work out the puzzles and find } \\
\text { the words } \\
\text { Multiple choice }\end{array}$ & 6 & 6 \\
Question5 & $\begin{array}{c}\text { Mulion } \\
\text { Total }\end{array}$ & 9 & 4 \\
\hline
\end{tabular}

10.1.3. Instructions of the Test (For Students)

The instructions were given to students by their teacher. He has to tell students that the test was designed for a scientific research purpose and it has nothing to do with their marks.

\subsubsection{The Pilot Study}

In December 2012, the test was administered to by a pilot sample of (30) eleventh graders in Abdul Kareem Al-Aklook secondary School for boys in Dair Alballah, who have the same characteristics of the study sample. The results were recorded and statistically analyzed to estimate the validity and the reliability of the test. The clarity of the questions was checked. The misleading items were also modified. The researchers found that students are suffering from low achievement in learning English vocabulary and the retention of the vocabulary they learned in grade 10 .

\subsubsection{Time Estimation}

The trial application helped in estimating the time needed for answering the questions according to the following equation: Time of the first student + time of the last student 2 . Therefore the time of test was (40) minutes

\subsubsection{The Validity of the Test}

Al Agha (1996: 118) states that a valid test is the test that measures what it is designed to measure. The study used the referee validity and the internal consistency validity.

\subsubsection{The Referee Validity}

The test was introduced to a jury of specialists in the English language and methodology in Gaza universities, Ministry of Education and supervisors and experienced teachers in the governmental schools. The items of the test were modified according to their recommendations.

\subsubsection{The Internal Consistency Validity}

Al Agha (1996: 121) asserts that the internal consistency validity indicates the correlation of the score of each item with the total average of the test. It also indicates the correlation of the average of each skill with the total average. This validity was calculated by using Pearson Formula.

Table 3. Correlation coefficient of every item of the test with the total score of the test

\begin{tabular}{ccc}
\hline No. & $\begin{array}{c}\text { Pearson } \\
\text { Correlation }\end{array}$ & Sig. level \\
\hline 1 & $0.695 * *$ & Sig. At 0.01 \\
2 & $0.736^{* *}$ & Sig. At 0.01 \\
3 & $0.564 * *$ & Sig. At 0.01 \\
4 & $0.584 * *$ & Sig. At 0.01 \\
\hline
\end{tabular}




\begin{tabular}{|c|c|c|}
\hline 5 & $0.617 * *$ & Sig. At 0.01 \\
\hline 6 & $0.665 * *$ & Sig. At 0.01 \\
\hline 7 & $0.889 * *$ & Sig. At 0.01 \\
\hline 8 & $0.712 * *$ & Sig. At 0.01 \\
\hline 9 & $0.697^{* *}$ & Sig. At 0.01 \\
\hline 10 & $0.518^{* *}$ & Sig. At 0.01 \\
\hline 11 & $0.621 * *$ & Sig. At 0.01 \\
\hline 12 & $0.774 * *$ & Sig. At 0.01 \\
\hline 13 & $0.768^{* *}$ & Sig. At 0.01 \\
\hline 14 & $0.631 * *$ & Sig. At 0.01 \\
\hline 15 & $0.837^{* *}$ & Sig. At 0.01 \\
\hline 16 & $0.412^{*}$ & Sig. At 0.05 \\
\hline 17 & $0.643 * *$ & Sig. At 0.01 \\
\hline 18 & $0.528 * *$ & Sig. At 0.01 \\
\hline 19 & $0.382 *$ & Sig. At 0.05 \\
\hline 20 & $0.455^{*}$ & Sig. At 0.05 \\
\hline 21 & $0.457^{*}$ & Sig. At 0.05 \\
\hline 22 & $0.629 * *$ & Sig. At 0.01 \\
\hline 23 & $0.673^{* *}$ & Sig. At 0.01 \\
\hline 24 & 0.577 ** & Sig. At 0.01 \\
\hline 25 & $0.764 * *$ & Sig. At 0.01 \\
\hline 26 & $0.611^{* *}$ & Sig. At 0.01 \\
\hline 27 & $0.775^{* *}$ & Sig. At 0.01 \\
\hline 28 & $0.392 *$ & Sig. At 0.05 \\
\hline 29 & $0.621 * *$ & Sig. At 0.01 \\
\hline 30 & $0.556^{* *}$ & Sig. At 0.01 \\
\hline
\end{tabular}

"r" table value at(28) df. At (0.05) sig. level equal 0.361

"r" table value at(28) df. At (0.01) sig. level equal 0.463

According to table (3), the coefficient correlation of each item is significant at (0.01)and (0.05). It can be concluded that the test is highly consistent and valid to be used as a tool of the study.

\subsubsection{Reliability of the Test}

The test is regarded reliable when it gives the same results in case of re-applying it for the same purpose in the same conditions (Al-Agha, $1996: 120)$.. The reliability of the test was measured by the Spilt- half techniques.

\subsubsection{Split Half Method}

It depended on splitting the test into two parts and calculating the correlation between the parts, then making a correction for the correlation coefficient by Spearman-Brown Prophecy Formula (Abu Hattab \& Sadeq, 1980: 14).

Table 4. Alpha Spilt-half Coefficient of the Achievement Test

\begin{tabular}{ccc}
\hline Alpha Spilt-half & $\begin{array}{c}\text { Number of } \\
\text { items }\end{array}$ & Test \\
\hline 0.889 & 30 & Vocabulary test \\
\hline
\end{tabular}

The results showed that the reliability coefficients were acceptable because they were above 0.70 (O'dah, 2002: 176), the Alpha Spilt-half coefficient is $(0.889)$ and this result assures the high reliability of the test.

The results showed that the reliability coefficients were acceptable because they were above 0.70 which means that the test was reliable and valid to apply.

\subsubsection{Scoring of the Test}

The test was scored by a simple traditional way. Each correct answer was awarded one point. The maximum average was (30) and the minimum was (zero). So, the total points for the whole test were 30 .

\subsubsection{Difficulty Coefficient}

Difficulty coefficient is measured by finding out the percentage of the wrong answers of each item made by the students ( Abu Nahia ,1994 :308). The coefficient of difficulty of each item was calculated according to the following formula: Co. of difficulty $=$ Number of students who gave wrong answers $\times 100$

Total number of student Table shows that the difficulty coefficient of the test items varied between (33.3- 80). Thus, all the items were accepted and the test is suitable to be used as a tool of the study.

\subsubsection{Discrimination Coefficient}

That means that the test is able to differentiate between the high achievers and the low achievers. The discrimination coefficient was calculated according to the following formula: Co. of Disc. $=$ correct answers number in higher group - correct answers number in lower group $\times 100$ Students number of one group.

Table 5. Difficulty and Discrimination of Items of the Test

\begin{tabular}{|c|c|c|}
\hline No. & Difficulty coefficient & Discrimination coefficient \\
\hline 1 & 60 & 33.3 \\
\hline 2 & 63.3 & 46.6 \\
\hline 3 & 66.6 & 33.3 \\
\hline 4 & 56.6 & 66.23 \\
\hline 5 & 73.3 & 46.6 \\
\hline 6 & 46.6 & 40 \\
\hline 7 & 36.6 & 53.3 \\
\hline 8 & 46.6 & 40 \\
\hline 9 & 53.3 & 66.23 \\
\hline 10 & 36.6 & 53.3 \\
\hline 11 & 33.3 & 46.6 \\
\hline 12 & 50 & 53.3 \\
\hline 13 & 53.3 & 46.6 \\
\hline 14 & 63.3 & 46.6 \\
\hline 15 & 76.6 & 60 \\
\hline 16 & 73.3 & 53.3 \\
\hline 17 & 73.3 & 53.3 \\
\hline 18 & 46.6 & 60 \\
\hline
\end{tabular}




\begin{tabular}{lcc}
\hline 19 & 80 & 73.3 \\
20 & 73.3 & 60 \\
21 & 43.3 & 40 \\
22 & 60 & 60 \\
23 & 53.3 & 73.3 \\
24 & 70 & 53.3 \\
25 & 63.3 & 66.23 \\
26 & 73.3 & 66.23 \\
27 & 33.3 & 53.3 \\
28 & 53.3 & 66.23 \\
29 & 40 & 63 \\
30 & 73.3 & 60 \\
\hline
\end{tabular}

Results show that the discrimination coefficient wobble between $(33.3-73.3)$ that means each of items is acceptable or in the normal limit of discrimination according to assessment and evaluation specialists.

\subsection{The language Puzzles}

In this study, puzzles were developed by the researchers from

\subsubsection{The Aim of the Puzzles}

The researchers used different puzzles to teach vocabulary for tenth graders. The puzzles were used to teach units $(6-7-8)$ of "English for Palestine 10 " for the experimental group.

\subsubsection{Developing the Puzzles}

While developing the puzzles, the following aspects were taken into consideration:

-The aim of each language puzzle.

-The method and the directions of each puzzle.

-Achieving the objective of the lesson.

-Increasing students' motivation by limiting time for some puzzles.

The worksheets used to teach the vocabulary.

\subsubsection{The Validity of the Puzzles}

To test the puzzles validity, the researcher submitted puzzles to a group of specialists in English language teaching, some English language supervisors and teachers to be judged and criticized.

The researcher did the required adjustment according to their recommendations.

After developing the puzzles and adjusting them in their final form, the researchers used different types of puzzles as follows:

\subsubsection{Crossword}

Words are filled into a pattern of numbered squares in answer to correspondingly numbered clues and in such a way that the words read across and down. Students are asked to find out words relevant to a certain topic whether vertically or horizontally.

\subsubsection{Picture Puzzles (Spot the Difference)}

It is a type of puzzle where students are asked to look carefully at the two pictures to find one difference or more between two the pictures.

\subsubsection{Anagram}

It is a type of word play, the result of rearranging the letters of a word or phrase to produce a new word or phrase, using all the original letters exactly once. In this puzzle, students are asked to arrange letters to form new word .

\subsubsection{The Spy Code}

It is a word game where students are asked to break a code to find words. Students in groups try to break a code of numbers by substituting letters them with letters.

\subsubsection{A Guessing Game}

It is a game in which the object is to guess some kind of information, such as a word, a phrase, a title, or the location of an object.

\section{Results: Data Analysis}

The study aimed at investigating the effectiveness of using puzzles in developing tenth graders ' vocabulary achievement and retention. This chapter tackles the procedures, the findings and results of the study in regards to the research questions. The researchers used different statistical forms using the statistical program (SPSS) to analysis the collected data results. Tables were also used to clarify and present these data with analysis and interpretation.

To answer this question, the researchers tested the following null hypothesis:

There are no statistically significant differences at $(\alpha \leq$ $0.05)$ in the average score in vocabulary achievement between the pupils who learned through puzzles (experimental group) and those who learned through the traditional method (control group) in the post test

To examine this hypothesis, means and standard deviation of both groups' results on the post-test were computed. Independent Samples T-test was used to measure the significant differences. Table (20) describes this

Table 6. T.test Independent Sample Results of Differences between the Experimental and the Control Group in the Post Test

\begin{tabular}{ccccccc}
\hline $\begin{array}{c}\text { sig. } \\
\text { level }\end{array}$ & $\begin{array}{c}\text { Sig. (2 } \\
\text { tailed) }\end{array}$ & T. & $\begin{array}{c}\text { Std. } \\
\text { Deviati } \\
\text { on }\end{array}$ & Mean & $\mathbf{N}$ & sample \\
\hline $\begin{array}{c}\text { Sig. at } \\
0.01\end{array}$ & .000 & $\begin{array}{c}3 . \\
66\end{array}$ & 7.48 & 18.60 & 40 & Experimental \\
\hline
\end{tabular}

"t" table value at ( 78) df. At (0.05) Sig. level equal 2.00

"t" table value at ( 78) df. At (0.01) Sig. level equal 2.66

As shown in table (20) shows that the T. computed value is larger than $\mathrm{T}$. table in the test which means that there are significant differences at $(a \leq 0.01)$ in the total average score 
of the post-test between the experimental and control group in favor of the experimental group. The mean of the post-test in the experimental group reached (18.60), whereas the mean of the control group was (12.27). This result indicates that using puzzles is more effective than the traditional method in developing the students' vocabulary.

To show the extent of puzzles' effect on the experimental group achievement in the vocabulary, the study applied the "Effect Size" technique. The researchers computed "2 $\eta$ " using the following formula :( Affana, 2000: 42)

$$
\text { t2 }
$$$$
{ }^{2} \eta=
$$

$$
\mathrm{t} 2+\mathrm{df}
$$

And "d" value using the following formula:

$\sqrt{2 t}$

Table 7. The Table References to Determine the Level of Size Effect $\left.{ }^{2} \eta\right)$ and (d)

\begin{tabular}{cccc}
\hline \multirow{2}{*}{ Test } & Small & $\begin{array}{c}\text { Effect size criterion } \\
\text { Medium }\end{array}$ & Large \\
\hline${ }^{2} \eta$ & 0.01 & 0.6 & 0.14 \\
$\mathrm{~d}$ & 0.2 & 0.5 & 0.8 \\
\hline
\end{tabular}

The results of " $\eta$ "and" $d$ " values shown in table (22) indicate large effect of using puzzles in the post test different

Table 8. The Effect Size of Puzzles on the Experimental and the Control Groups Achievement in the Post-Test

\begin{tabular}{cccccc}
\hline Test & df & T & ${ }^{2} \boldsymbol{\eta}$ & d & $\begin{array}{c}\text { Effect } \\
\text { size }\end{array}$ \\
\hline $\begin{array}{c}\text { Post test } \\
\text { (total ) }\end{array}$ & 78 & 3.664 & 0.146 & 0.829 & Large \\
\hline
\end{tabular}

Table (8) shows that the effect size of puzzles is large on students' vocabulary achievement. This means that the effect of puzzles is significant. This large effect may be due to the activities and techniques which are used in the different puzzles to develop students' vocabulary achievement.

To answer this question, the researchers tested the following null hypothesis there are no statistically significant differences at $(\alpha \leq 0.05)$ in the average score in the pre and post-test of the experimental group.

Table 9. T.Test Paired Sample Results of the Differences in the Total Average Score between the Pre-Test and the Post Test of the Experimental Group

\begin{tabular}{lllllll}
\hline $\begin{array}{l}\text { sig. } \\
\text { level }\end{array}$ & $\begin{array}{l}\text { Sig. (2 } \\
\text { tailed) }\end{array}$ & T. & $\begin{array}{l}\text { Std. } \\
\text { Deviatio } \\
\text { n }\end{array}$ & Mean & N & Application \\
\hline $\begin{array}{l}\text { Sig. } \\
\text { at } \\
0.01\end{array}$ & .000 & 12.9 & $\begin{array}{l}2.17076 \\
7.48\end{array}$ & 2.4250 & 40 & Pre test \\
\hline
\end{tabular}

"t" table value at ( 39) df. At (0.05) Sig. level equal 2.03

"t" table value at (39) df. At (0.01) Sig. level equal 2.75
As shown in table (23) shows that the T. computed value is larger than $\mathrm{T}$. table in the test which means that there are significant differences at $(a ́ 0.01)$ in the total average score of the post-test between the experimental and control group in favor of the experimental group. The mean of the post-test in the experimental group reached (18.60), whereas the mean of pre-test in the experimental group was (2.4250). This means that there are statistically significant differences between the pre and post application of the experimental group in favor of the post application. This means that using puzzles is very effective in the achievement of tenth graders' vocabulary.

Table(10) The Effect Size of Puzzles in the Pre- and the Post Test of the Experimental Group

\begin{tabular}{ccccc}
\hline Test & df & T & ${ }^{2} \boldsymbol{\eta}$ & Effect size \\
\hline total & 39 & 12.9 & 0.81 & Large \\
\hline
\end{tabular}

Table (10) shows that the effect size of puzzles is large on students' vocabulary achievement. This means that the effect of puzzles is significant.

Are there statistically significant differences at $(\alpha \leq 0.05)$ in the total average score between the post-test and delayed test of the experimental group?

To answer this question, the researchers tested the following null hypothesis

There are no statistically significant differences at $(\alpha \leq$ 0.05 ) in the total average score between the post-test and delayed test of the experimental group.

To answer the second question, means and standard deviation of both post-test and retention test results were computed. Paired sample T-Test was used to measure the significant differences.

Table 11. T.Test Paired Sample Results of the Differences in the Total Average Score between the Post-Test and the Delayed Test of the Experimental Group

\begin{tabular}{ccccccc}
\hline $\begin{array}{c}\text { sig. } \\
\text { level }\end{array}$ & $\begin{array}{c}\text { Sig. (2 } \\
\text { tailed) }\end{array}$ & T. & $\begin{array}{c}\text { Std. } \\
\text { Deviation }\end{array}$ & Mean & N & $\begin{array}{c}\text { applicatio } \\
\mathbf{n}\end{array}$ \\
\hline $\begin{array}{c}\text { Not } \\
\text { sig. }\end{array}$ & .438 & .783 & 7.48 & 18.60 & 40 & Post test \\
& & & 7.51 & 17.80 & 40 & $\begin{array}{c}\text { Delayed } \\
\text { test }\end{array}$ \\
\hline
\end{tabular}

"t" table value at ( 39) df. At (0.05) Sig. level equal 2.03

" $t$ " table value at (39) df. At (0.01) Sig. level equal 2.75

As shown in table (11) shows that the T. table value is less than T. computed value in the delayed test. That means there are no statistically significant differences at (á $\leq 0.05)$ in the total average score between the post-test and the delayed of the experimental group. The mean of the post -test was (18.60) while the mean of the delayed test was (17.80). This result indicates the long-term effect of using puzzle on the experimental group of vocabulary retention . 


\section{Discussion}

The study aimed at investigating the effectiveness of using puzzles in developing tenth graders ' vocabulary achievement and retention. To achieve this aim, the researchers adopted the experimental approach where therewere two equivalent groups: the experimental and the control groups. Each group included (40) students, purposively chosen from Abdul Kareem Al-Aklook secondary for boys in Dair Al

Balah. Both groups were proved to be equivalent in terms of age, vocabulary achievement. The researchers used three tools in order to collect data: an Achievement test (pre - post $\&$ delayed test) and teacher guide(puzzles).

The researchers prepared the teacher guide which is based on language puzzles to develop students' English vocabulary. The contents of the teacher guide were chosen, organized and modified according to the opinions and suggestions of a group of specialists in this field. The researchers prepared an implementation plan for the experiment. The experiment started at the beginning of the second semester of the school year (2012-2013) and lasted for six weeks. The researchers used a variety of techniques and activities based on puzzles. The population of the study consisted of all tenth graders at the governmental schools in the Middle-Area Directorate.

\section{Findings}

The following findings were observed:

1. There were statistically significant differences in the total average score in vocabulary achievement between the pupils who learned through puzzles (experimental group) and those who learned through the traditional method (control group) in favor of the experimental group with a large effect size.

2. There were statistically significant differences in the average score in the pre and post-test of the experimental group in favor of the post application.

3. There were no statistically significant differences in the total average score between the post-test and delayed test of the experimental group.

\section{This May be Attributed to}

1. The variety of techniques in presenting Puzzles .(picture puzzles, crosswords, anagram ad guessing game)

2. The puzzles are suitable to the students ' age.

3. The researchers used puzzle that suit to the Students ' minds.

4. Using different activities in the classroom.

5. Puzzle based teach motivated students to work while keeping them engaged and interested. They also created a relaxed, fun filled and anxiety-free atmosphere that facilitated and enhanced learning.

6. Using puzzles created a non-threatening learning environment that encouraged interactions between students and teachers, enhanced communication, cooperation and teamwork and encouraged active participation.

7. Using puzzles strategy proved to be a fertile teaching learning environment that enhanced both conscious and subconscious learning of vocabulary. Explicit learning is represented in the explicit instruction of puzzles of acquiring vocabulary. Indirect acquisition of vocabulary results from practicing the various activities and techniques which are used to develop vocabulary achievement. Consequently, it can be summed up that using puzzles is effective in developing English vocabulary.

8. Puzzles helped in the acquisition and learning of new words as well as increase students' familiarity with them in terms of meaning. Puzzles change the atmosphere of the class, add excitement to the learning environment, and create a naturalistic setting for language learning. Learners in the process of using puzzles have the opportunity to use language in order to convey meaning and use their knowledge to do something.

\section{Conclusion}

Based on the findings, derived from the results of this study, the following conclusions were reached:

1. Puzzles stimulate students towards an independent practice of English language instead of direct instruction.

2. Educational Puzzles provide a context in which language is used in a meaningful way and they helped students develop communicative competence in the English language. This also adds an interesting aspect to puzzles, the competition. Adding competition to educational puzzles is a good technique to try to push its players to learn

3. Puzzles provide students with enjoyment, pleasure, enthusiasm and variation which are significant enough to affect the students' achievement positively.

4. Puzzles can afford a valuable technique in language classroom for students at intermediate level and hence can be used to facilitate the process of vocabulary learning.

\section{Pedagogical Implications}

In the light of the study results, the researchers suggest the following:

1. Teachers should be aware of the needs of their students as well as their abilities and can accordingly choose suitable techniques for activating English vocabulary.

2. Teachers should avoid teacher-centered classes and encourage student-centered classes. And should use strategies which can promote learners 'motivation is 
considered as an effective strategy for language learning and teaching.

3. Teachers and students should be convinced of the importance of using puzzles in acquiring and developing vocabulary.

4. Teachers should be convinced that, through puzzles, learners are given opportunities to meet and explore new vocabulary without direct teacher assistance.

\section{Recommendations}

In the light of the results, the researchers recommend that: Curriculum designers and decision makers are recommended to enrich the Palestinian curriculum with different educational puzzles that tackle the different skills of English language .And Develop and enrich the Teacher's Guide with activities and techniques with different types of puzzles.

Supervisors are recommended to Provide teachers with instructional materials which improve their awareness about puzzles and their importance and the necessity of using them in teaching English. And Conduct workshops that aim at familiarizing teachers with different puzzles.

English language teachers are recommended to Change the methods and approaches of teaching from traditional to communicative which based on the students' real involvement in the teaching-learning process. And Change their role from instructors who dominate the class into educators whose role is to facilitate, guide, organize, help, coordinate and support the students to communicate and acquire the language.

\section{Recommendations for Further Studies}

The researchers suggested the following recommendations for further studies:

1. The effect of computerized competitions on developing students reading comprehension skills.

2. The effectiveness of using puzzles on developing listening comprehension skills.

3. The effect of educational puzzles on developing students' critical thinking.

4. The effectiveness of a suggested program based on puzzles on developing reading comprehension skills.

5. The effect of puzzle based learning on the development of self-learning.

\section{References}

[1] Abu Hattab \& Sadeq (1980). Educational Psychology. 2nd Edition, Cairo : Anglo Egyptian bookshop .

[2] Abu Nahia , S. ( 1994). Educational Measurement . 1st Edition, Cairo : Anglo Egyptian bookshop .

[3] Affana,A(2000)The effect size in educational reserches. Palestinian educational studies magazine. 3(6)
[4] Al-Agha, I. (1996). Educational Research, its elements, Methodology and Tools. The Internal Consistency Validity. (4th ed.). Gaza, Palestine: Islamic University.

[5] Al-Atawi,E (2011). The Effect of Using Games on First Grade Students Achievement in English Language Vocabulary in Tabouk district in Saudi Arabia. Unpublished master thesis .Hashemite university,Jordan.

[6] Alemi, M. (2010).Educational Games as a Vehicle to Teaching Vocabulary.MJAL.Modern journal of applied linguistics,2(6).

[7] Allen, E\& Valette, R (1977). Classroom Techniques: Foreign Languages and English As a Second Language. New York : Harcourt Brace Jovanovich

[8] Ardeo, J. (2003). Attitude towards English and ESP acquisition as an L2 or L3 at university Ibérica 6, 109-133. $\begin{array}{llll}\text { Retrieved } & 29 & \text { January }\end{array}$ http://www.aelfe.org/documents/text6-Gonzalez.pdf

[9] Bahrick, H. P. (1984). Semantic memory content in permastore: Fifty years of memory for Spanish learned in school, Journal of Experimental Psychology: General, 113, $1-29$.

[10] Bouteliaten,A. (2010). The Effectiveness of Using Crossword Puzzles as a Teaching Strategy to Enhance Students' Knowledge of Vocabulary. The Case of 1st Year Students, University of Constantine. Unpublished Master Dissertation, Mentouri University-Constantine.

[11] Cairns,R. \& Redman,S.(1986).Working with words :A guide to teaching and learning vocabulary. Britain: Cambridge university press.

[12] Chen, Y..H.; Lin, C.-P.; Looi, C.K.; Shao, Y.-j.\& Chan, T..W.(2012). A Collaborative Cross Number Puzzle Game to Enhance Elementary Students' Arithmetic Skills. Turkish Online Journal of Educational Technology - TOJET, 11 (2),p1-14 .(ERIC Document Reproduction Service No EJ989008)

[13] Decarrico ,J. (2001). Vocabulary learning and teaching . In Teaching English as a second or foreign language. Celce-Murcia, Marianne (ed.). Boston: Heinle and Heinle. 285-299

[14] Farlex, (2009). The Online Free Dictionary. Retrieved 27 Augest 2012http://www.thefreedictionary.com

[15] Graddol, D.; Cheshire, J.\& Joan S. (1987). Describing language . Open university press :Philadelphia USA.

[16] Khabiri,M. \& Pakzad,M. (2012) The Effect of Teaching Critical Reading Strategies on EFL Learners' Vocabulary Retention. The Journal of Teaching Language Skills (JTLS), 4 (1),73-106.Retrieved 28 February 2013 http://www.sid.ir/en/VEWSSID/J_pdf/13112012660404.pdf

[17] Laraba, S.(2007) Developing Vocabulary Strategies In Learners Of English At University Level: First -Year L.M.D Students .Unpublished PH.D thesis . Mentouri University, Algeria

[18] Lawson, M. J \& Hogben, D.(1996). The Vocabulary-Learning Strategies of Foreign-Language Students . Language Learning 46(1), March 1996, pp. $101-135$ 
[19] Merrick, K. E.(2010). An Empirical Evaluation of Puzzle-Based Learning as an Interest Approach for Teaching Introductory Computer Science .IEEE Transactions on Education, v53 n4 p677-680 . (Eric Document Reproduction Service No. EJ905553)

[20] Mohammed, E. F. (2009). The Effectiveness of TPRS in Vocabulary Acquisition and Retention of EFL Prep. Stage Students and their Attitude towards English Language. Unpublished MA Thesis, Mansoura University, Egypt.

[21] Khabiri,M. \& Pakzad,M. (2012) The Effect of Teaching Critical Reading Strategies on EFL Learners' Vocabulary Retention. The Journal of Teaching Language Skills (JTLS), 4 (1),73-106.Retrieved 28 February 2013 http://www.sid.ir/en/VEWSSID/J_pdf/13112012660404.pdf

[22] Laraba, S.(2007) Developing Vocabulary Strategies In Learners Of English At University Level: First -Year L.M.D Students .Unpublished PH.D thesis . Mentouri University, Algeria

[23] Lawson, M. J \& Hogben, D.(1996). The Vocabulary-Learning Strategies of Foreign-Language Students . Language Learning 46(1), March 1996, pp. $101-135$

[24] Merrick, K. E.(2010). An Empirical Evaluation of Puzzle-Based Learning as an Interest Approach for Teaching Introductory Computer Science .IEEE Transactions on Education, v53 n4 p677-680 . (Eric Document Reproduction
Service No. EJ905553)

[25] Mohammed, E. F. (2009). The Effectiveness of TPRS in Vocabulary Acquisition and Retention of EFL Prep. Stage Students and their Attitude towards English Language. Unpublished MA Thesis, Mansoura University, Egypt.

[26] Nation, I.S.P. (1990) Teaching and Learning Vocabulary New York: Newbury House.

[27] Richards, C J \& Renandya A.W(2002).Methodology in language teaching an anthology of current practice.UK: Cambridge university press

[28] Richards, C J (2001). Curriculum development in language teaching, CUP.UK: Cambridge university press.

[29] Scrivener, J. (1994) Learning Teaching: a guidebook for English language teachers . Oxford: Heinemann.

[30] Tassana-ngam, I.,(2004) The Effect of Vocabulary Learning Strategies Training on Thai University Students' Word Retention in the Second Language Classroom. Unpublished PHD thesis, University of Essex. Retrieved 19 February 2013http://pirun.ku.ac.th/ fhumirt/phd.pdf

[31] Thornbury, s. (2002) How to teach vocabulary. Person education limited: England.

[32] Wilkins, D.A. (1972).Linguistics in language teaching. London: Edward Arnold Ltd. 